\title{
MEDIA DEMONSTRASI DAN EKSPERIMEN BERBASIS ANIMASI: EFEKTIFITAS MENINGKATKAN KETERAMPILAN SISWA MEMECAHKAN MASALAH DI ERA REVOLUSI INDUSTRI 4.0
}

\section{Marlina $^{1}$, Samsul Hadi2 ${ }^{2}$ Abdul Rahim ${ }^{3}$}

\author{
1,3 Jurusan Penelitian dan Evaluasi Pendidikan, Universitas Negeri Yogyakarta, Yogyakarta, Indonesia \\ ${ }^{2}$ Jurusan Pendidikan Teknik Elektro, Universitas Negeri Yogyakarta, Yogyakarta, Indonesia \\ *Corresponding Author: marlina0177pasca.2019@student.uny.ac.id
}

\section{ART I CLE I N F O}

Article history:

Received April 10, 2021

Revised April 11, 2021

Accepted September 20, 2021

Available online October 25, 2021

Kata Kunci:

Media Animasi;

Keterampilan

Memecahkan Masalah

Keywords:

Animation Media; Problem

Solving Skills

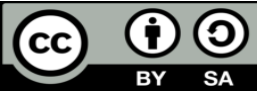

This is an open access article under the CC BY-SA license.

Copyright (C) 2021 by Author. Published by Universitas Pendidikan Ganesha.

\begin{abstract}
A B S T R A K
Kesulitan yang dialami siswa dalam mempelajari kelarutan dan hasil kali kelarutan, masih banyak siswa belum memahami konsep prasyarat, seperti konsep mol, reaksi ionisasi, kesetimbangan kimia, $\mathrm{pH}$ larutan asam dan basa. Kesulitan siswa juga dikarenakan kurangnya guru memberikan contoh-contoh tentang reaksi-reaksi yang ada di lingkungan sekitar yang sering dijumpai siswa Penelitian ini bertujuan menganalisis efekktifitas media demonstrasi dan eksperimen berbasis animasi dalam meningkatkan keterampilan pemecahan masalah siswa di era revolusi industri 4.0. Jenis penelitian menggunakan Quasi Eksperimen dengan Nonequivalent Pretest Posttest Control Group Design. Subjek penelitian ini adalah 50 siswa kelas XI MIPA yang dibagi menjadi 27 siswa pada kelas eksperimen dan 24 siswa pada kelas control. Data dikumpulkan menggunakan metode tes. Teknik analisiss data menggunakan analisis kuantitatif. Hasil penelitian menunjukkan uji prasyarat normalitas dan homogenitas diperoleh nilai signifikansi $>0,05$. Hasil uji paired sample $t$ test diperoleh Sig. 0,00<0,05 menunjukan pretest dan posttest kelas eksperimen maupun kelas kontrol berbeda signifikan. Hasil uji Independent sample t-test diperoleh Sig. (2-tailed) 0,018<0,05 sehingga ada perbedaan rata-rata antara kelas eksperimen dan kelas kontrol untuk meningkatkan keterampilan siswa dalam memecahkan masalah. Perbedaan rata-rata kelas eksperimen $>$ rata-rata kelas kontrol yaitu $80>$ 70. Itu berarti bahwa media demonstrasi dan eksperimen berbasis video animasi efektif digunakan pada proses pembelajaran.
\end{abstract}

\section{A B S T R A C T}

The difficulties experienced by students in studying solubility and solubility products, there are still many students who do not understand the prerequisite concepts, such as the concept of moles, ionization reactions, chemical equilibrium, $\mathrm{pH}$ of acid and base solutions. Students' difficulties are also due to the lack of teachers providing examples of reactions in the surrounding environment that students often encounter. This study aims to analyze the effectiveness of animation-based demonstration and experimental media in improving students' problem solving skills in the industrial revolution 4.0 era. This type of research uses a Quasi Experiment with Nonequivalent Pretest Posttest Control Group Design. The subjects of this study were 50 students of class XI MIPA consisting of 27 students in the experimental class and 24 students in the control class. Methods of data collection using the test method. The data analysis technique uses quantitative analysis. The results showed that the prerequisite test for normality and homogeneity obtained a significance value $>0.05$. The results of the paired sample t-test were obtained by Sig. $0.00<0.05$ indicates that the pretest and posttest of the experimental class and the control class are significantly different. Test results Independent sample $t$ test obtained Sig. (2-tailed) $0.018<0.05$ so that there is an average difference between the experimental class using demonstration media and video animation-based experiments and the control class using power point to improve students' problem-solving skills. The difference in the experimental class average $>$ the control class average is $80>70$. So the demonstration and experimental video based animation media for the solubility product and the solubility product are effectively used in the learning process. 


\section{PENDAHULUAN}

Era revolusi industri 4.0 merupakan era dimana pengetahuan dan teknologi berkembang dengan sangat cepat yang mengakibatkan perubahan cepat dan kompetitif yang ditandai dengan berkembang pesat teknologi (Agussani, 2020; Hussin, 2018). Era revolusi industri 4.0 juga membawa tantangan bagi sistem pendidikan. Pendidikan merupakan salah satu solusi untuk meningkatkan kualitas sumber daya manusia di era revolusi industri 4.0 (Agussani, 2020; Rahim et al., 2020). Paradigma revolusi yang terus berkembang secara berkala diprakarsai oleh kemajuan ilmu pengetahuan dan teknologi sebagai pendukung pembaharuan (Liao et al., 2018). Bahwa menguasai teknologi mengalami perubahan yang pesat di era revolusi industri 4.0 yakni menuntut guru mampu mengaplikasikan segala bentuk teknologi dan informasi dalam pembelajaran. Sedangkan, siswa era ini adalah generasi milenial yang tidak bisa hidup tanpa smart gadget dan internet (Cotet et al., 2020). Hal tersebut dapat dimanfaatkan untuk mengembangkan teknologi dalam pembelajaran. Salah satunya mendukung era revolusi industri 4.0 dalam bidang pendidikan dengan mengembangakan media pembelajaran yang dapat diakses siswa. Kemajuan pendidikan mengalami perkembangan signifikan terhadap perubahan kurikulum dalam meningkatkan hasil belajar. Keberhasilan siswa dalam mengkonstruksi ilmunya tidak hanya dari pencapaian tujuan pembelajaran yang telah ditentukan (Nessa et al., 2017), akan tetapi siswa juga harus mampu mengaplikasikan konsep-konsep pengetahuan yang diperoleh di sekolah untuk memecahkan masalah yang dihadapi dalam kehidupan sehari-hari secara relevan, bermakna, dan kontekstual (Khairunnufus et al., 2019).

Pembelajaran di era pandemi Covid-19 mengalami problematika di dunia pendidikan. Pembelajaran yang dilakukan secara online memiliki pro dan kontra yang dirasakan oleh elemen sekolah (Quezada et al., 2020; Widikasih et al., 2021). Pemanfaatan teknologi begitu sangat dibutuhkan dampaknya oleh guru dan siswa, saat pembelajaran jarak jauh (Chang et al., 2021; Fadhilaturrahm et al., 2021; Wijayanti \& Fauziah, 2020). Berbagai macam bentuk komunikasi dilakukan oleh guru untuk menunjang pembelajaran jarak jauh serta teknologi yang digunakan telah diterapkan baik dalam bentuk visual, audio, dan audio visual (Muhammad Fikri, Muhammad Zaki Ananda, 2021; Syafari \& Montessori, 2020). Namun, masih banyak guru yang penguasaan teknologi masih rendah sehingga pembelajaran online belum optimal (Anthony, 2019; Atmojo et al., 2020; Martin et al., 2019; Rasmitadila et al., 2020). Pemanfaatan teknologi dan komunikasi dalam pembelajaran merupakan bagian penting dalam mendukung pembelajaran saat ini serta mengalami perubahan pada sektor teknologi dan komunikasi yang terlihat dalam era revolusi industri 4.0. Khususnya pada pembelajaran kimia. Kimia merupakan materi yang dianggap paling sulit oleh sebagian besar siswa SMA (Kartikawati \& Azizah, 2017). Hal ini ditunjukan dengan hasil belajar siswa yang relatif rendah pada pelajaran kimia (Sudiana et al., 2019). Kesulitan yang dialami siswa dalam mempelajari kelarutan dan hasil kali kelarutan, masih banyak siswa belum memahami konsep prasyarat, seperti konsep mol, reaksi ionisasi, kesetimbangan kimia, $\mathrm{pH}$ larutan asam dan basa, serta kesulitan dalam menghubungkan antar konsep (Hidayah et al., 2013). Kesulitan siswa juga dikarenakan kurangnya guru memberikan contoh-contoh tentang reaksi-reaksi yang ada di lingkungan sekitar yang sering dijumpai siswa (Khairunnufus et al., 2019; Sudiana et al., 2019). Sebagian besar siswa-siswi mengalami kesulitan dalam memahami konsep kelarutan dan hasil kali kelarutan (Ulfah et al., 2016). Jika permasalahan tersebut dibiarkan akan memberikan dampak buruk terhadap pendidikan.

Pengembangan teknologi dalam pendidikan seperti media pembelajaran yang dapat digunakan sebagai alat untuk pemecahan permasalahan siswa dalam kegiatan belajar mengajar. Dimana penggunaan teknologi saat ini akan membantu siswa belajar lebih baik (Adnan et al., 2017; Baharuddin \& Dalle, 2018; Tomita, 2018). Teknologi digital menawarkan banyak peluang untuk membuat konten yang menarik untuk media pembelajaran (Adnan et al., 2017; W. Tabor \& P. Minch, 2013). Bahwa penggunaan teknologi digital sebagai media pembelajaran memiliki dampak yang lebih baik dan efektif dibandingkan yang lain (Adnan et al., 2017; Asmawati, 2021). Media pembelajaran merupakan salah satu alat yang mempengaruhi proses pembelajaran untuk meningkatkan minat belajar siswa, perlu didukung media pembelajaran yang menarik (Ntobuo et al., 2018; E. S. Wahyuni \& Yokhebed, 2019). Media pembelajaran lazimnya digunakan guru pada saat penyajian materi dengan maksud agar materi yang sulit dipahami, materi yang tadinya abstrak menjadi lebih mudah dimengerti, serta menghindari terjadinya miskonsepsi (N. Q. Panjaitan et al., 2020; R. G. P. Panjaitan et al., 2020; Primasari \& Herlanti, 2015). Bentuk media pembelajaran dapat berupa visual, audio, maupun audio visual. Media pembelajaran adalah salah satu komponen penting dalam penunjang keberhasilan belajar (Anggreini \& Dewi, 2020; Fauzi et al., 2017; Santhalia \& Sampebatu, 2020). Video adalah teknologi penangkapan, perekaman, pengolahan, penyimpanan, pemindahan, dan perekonstruksian urutan gambar diam dengan menyajikan adegan-adegan dalam gerak secara elektronik (Darihastining et al., 2020; W. Tabor \& P. Minch, 2013). Media animasi ini merupakan gabungan antara gambar, tulisan, suara dan animasi yang bergerak, yang dipakai dalam memudahkan seseorang memahami materi (Anjarsari et al., 2020; Dwijayanti et al., 2020; N. Q. Panjaitan et al., 2020). Video animasi untuk pembelajaran 
memberikan pesan menggunakan visual dan efek audio, sehingga menarik perhatian siswa dan membawa contoh langsung peristiwa yang tidak dapat digambarkan dengan verbalisme bisa diproyeksikan ke dalam bentuk nyata ke dalam kelas (Hua et al., 2020; Wouters et al., 2019).

Beberapa temuan terkait pemanfaatan teknologi pendidikan menyatakn dengan memanfaatkan teknologi seperti game science adventure untuk meningkatkan keterampilan pemecahan masalah (Naimah et al., 2019). Menggunakan media pembelajaran berbasis video yang dikembangkan mempunyai prestasi yang lebih baik dibandingkan dengan kelompok yang menggunakan media buku bergambar (Fadhli, 2015). Menggunakan media animasi hukum Newton tentang gerak pada bidang miring dan katrol terbukti dapat menarik dan meningkatkan minat siswa (Muslina et al., 2018). Dalam mendukung pembelajaran di era revolusi 4.0 untuk meningkatkan keterampilan siswa dalam memecahkan masalah pada materi kelarutan dan hasil kali kelarutan. Media demonstrasi dan eksperimen diujikan kelayakan oleh validator ahli materi, media dan tiga guru kimia dengan memiliki kualitas dan kelayakan sangat baik (SB) dengan persentase 82\% serta telah diujicobakan 60 siswa dari tiga sekolah SMAN 2 Sleman, SMAN 1 Cangkringan, dan MA Taruna Quran memiliki kualitas dan kelayakan sangat baik dengan persentase masing-masing 87\%; 85\%; dan 86\%. Oleh karena itu, akan dilakukan penerapan media pembelajaran untuk menguji efektifitas media demonstrasi dan eksperimen berbasis video animasi untuk meningkatkan keterampilan siswa dalam memecahkan masalah materi kimia kelarutan dan hasil kali kelarutan sebagai pembelajaran. Tujuan dari penelitian ini untuk menganalisis efektivitas media demonstrasi dan eksperimen berbasis video animasi dalam pembelajaran untuk meningkatkan keterampilan siswa dalam pemecahan masalah.

\section{METODE}

Penelitian ini dilaksanakan di salah satu Sekolah Menengah Atas Negeri di Kota Tegal dengan jumlah sebanyak 50 siswa yang terbagi menjadi 2 kelas. Jenis penelitian ini merupakan Quasi-Experiments dengan Nonequivalent Pretest-Posttest Comparison Group Design (Purwaningsih et al., 2020). Ada dua kelas yang terlibat, yaitu kelas eksperimen dan kelas kontrol. Pengambilan sampel secara purposive sampling yang artinya sampel ditentukan peneliti sehingga tidak mengubah struktur kelas yang telah ditetapkan, akan tetapi kedua kelas tersebut telah ditentukan pada kemampuan yang sama berdasarkan data penilaian guru. Subjek penelitian ini dilibatkan sebanyak 50 siswa kelas XI MIPA yang terdiri dari 27 siswa pada kelas eksperimen dan 24 siswa pada kelas kontrol. Pada kelas eksperimen diberikan perlakuan dengan menerapkan pembelajaran menggunakan bantuan media demonstrasi dan eksperimen berbasis video animasi. Sedangkan, kelas kontrol diberikan pembelajaran menggunakan power point yang akan dijelaskan oleh guru secara konvensional. Kedua kelas tersebut dilakukan pembelajaran secara online dengan perlakuan yang berbeda. Bahwa pengambilan data dilakukan secara dua kali pertemuan untuk kelas eksperimen dan kelas kontrol. Setelah pembelajaran selesai dilanjutkan dengan pemberian soal posttest untuk masing-masing kelas. Walaupun pembelajaran dilakukan secara online, akan tetapi siswa dituntun memiliki keterampilan dalam memecahkan masalah melalui soal posttest kelarutan dan hasil kali kelarutan. Variabel terikat dalam penelitian ini adalah materi kelarutan dan hasil kali kelarutan. Instrumen pengukuran yang digunakan adalah tes yang terdiri dari masing- masing 10 butir soal pilihan ganda untuk pretest dan posttest yang mencakup ranah kognitif dengan empat indikator meliputi: mengenali masalah, merepresentasikan masalah sesuai teori, menyelesaikan masalah, dan mengevaluasi. Data diuji dengan menggunakan statistik inferensial. Uji homogenitas dan normalitas hasil pretest dan posttest dilakukan sebelum menguji hipotesis. Pengujian hipotesis pilih berdasarkan hasil pengujian awal. Analisis data digunakan untuk mengetahui efektifitas sebelum dan sesudah perlakuan yaitu menggunakan teknik analisis paired sample t-tes

\section{HASIL DAN PEMBAHASAN}

\section{Hasil}

Tahap penetapan materi video animasi dengan mengetahui karakteristik materi kelarutan dan hasil kali kelarutan bersifat abstrak dan belum ada materi yang menerapkan materi tersebut, sehingga diperlukan media untuk materi kelarutan dan hasil kali kelarutan. Pada jenjang anak sekolah menengah atas cenderung lebih mengedepankan pembelajaran dengan penyampaian menarik, apalagi pada saat pembelajaran secara daring. Hasil analisis kebutuhan menujukkan pembelajaran untuk meteri tersebut masih secara konvensional dengan bantuan buku cetak dan LKPD. Hasil observasi menujukkan bahwa sebagaian siswa belum pernah mengaplikasikan video animasi dalam pembelajaran. Video animasi yang berisikan pemahaman teori, aplikasi dalam kehidupan sehari- hari, demonstrasi dan eksperimen secara visual laboratorium. Media telah ujicobakan pada tiga sekolah menengah atas dengan jumlah 60 siswa dengan hasil produk memenuhi kelayakan untuk diterapkan dalam pembelajaran. Efektifitas dari media 
demonstrasi dan eksperimen berbasis video animasi, maka dilakukan eksperimen menggunakan desain pretest dan posttest dengan teknik analisis statistik uji Paired sample t-tes dan independent sample t-tes.

Berdasarkan hasil analisis, nilai yang diperoleh dari 50 siswa dengan mean pretest eksperimen sebesar 40,37 dan mean pretest kontrol sebesar 40,43. Hasil ini berarti siswa pada kedua kelas tersebut memiliki kemampuan pemecahan masalah yang sama dan tidak terpengaruh oleh pembelajaran sebelumnya. Tabel 2 menunjukkan nilai Sig. eksperimen 0,011 dan nilai Sig. kontrol 0,019 dimana nilai $\alpha=$ 0,05, karena nilai Sig. $<0,05$ sehingga dapat disimpulkan bahwa data nilai pretest dan posttest sangat berkorelasi, dimana nilai korelasi eksperimen sebesar 0,48 atau sebesar $48 \%$, sedangkan nilai korelasi kontrol sebesar 0,484 atau sebesar 48,4\%. Tabel 3 menunjukkan nilai Sig. eksperimen 0,00 dan nilai Sig. kontrol 0,00 dimana nilai $\alpha=0,05$, karena nilai Sig. $<\alpha$ dapat disimpulkan bahwa nilai pretest dan posttest kelas eksperimen maupun kelas kontrol sangat berbeda signifikan. Jika dilihat dari rataan marginal, diketahui bahwa nilai posttest lebih besar dari nilai pretest. Sehingga dapat disimpulkan bahwa ada pengaruh yang sangat signifikan penggunaan media demonstrasi dan eksperimen berbasis video animasi dan power point untuk meningkatkan keterampilan siswa dalam memecahkan masalah. Dengan kata lain, media demonstrasi dan eksperimen berbasis video animasi dan power point tersebut efektif untuk digunakan dalam proses pembelajaran. Tabel 4 diperoleh nilai Sig.(2-tailed) sebesar 0,018 $<0,05$ maka dapat disimpulkan ada perbedaan rata-rata antara penggunaan media demonstrasi dan eksperimen berbasis video animasi dan power point untuk meningkatkan keterampilan siswa dalam memecahkan masalah.

Berdasarkan analisis data dengan menggunakan uji statistik Independent $t$ test diperoleh nilai signifikansi sebesar 0,018 dimana nilai tersebut lebih kecil dari nilai signifikansi $(\alpha=0,05)$ yang menunjukkan bahwa Ho ditolak dan Ha diterima. Hasil ini menunjukkan bahwa secara statistik terdapat perbedaan yang signifikan antara keterampilan pemecahan masalah siswa yang belajar menggunakan media demonstrasi dan eksperimen berbasis video animasi pada kelas eksperimen diperoleh mean sebesar 80 dengan siswa yang belajar menggunakan power point diperoleh mean sebesar 70. Penelitian ini menunjukkan bahwa pengaruh media demonstrasi dan eksperimen lebih baik dalam meningkatkan keterampilan pemecahan masalah siswa daripada pembelajaran menggunakan power point. Berdasarkan analisis data dengan menggunakan uji statistik Independent $t$ test diperoleh nilai signifikansi sebesar 0,018 dimana nilai tersebut lebih kecil dari nilai signifikansi $(\alpha=0,05)$ yang menunjukkan bahwa Ho ditolak dan Ha diterima. Hasil ini menunjukkan bahwa secara statistik terdapat perbedaan yang signifikan antara keterampilan pemecahan masalah siswa yang belajar menggunakan media demonstrasi dan eksperimen berbasis video animasi pada kelas eksperimen diperoleh mean sebesar 80 dengan siswa yang belajar menggunakan power point diperoleh mean sebesar 70 . Penelitian ini menunjukkan bahwa pengaruh media demonstrasi dan eksperimen lebih baik dalam meningkatkan keterampilan pemecahan masalah siswa daripada pembelajaran menggunakan power point.

\section{Pembahasan}

Berdasarkan hasil penelitian ditemukan beberapa hasil. Pertama, ada pengaruh yang sangat signifikan penggunaan media demonstrasi dan eksperimen berbasis video animasi dan power point untuk meningkatkan keterampilan siswa dalam memecahkan masalah. Dengan kata lain, media demonstrasi dan eksperimen berbasis video animasi dan power point tersebut efektif untuk digunakan dalam proses pembelajaran. Hal tersebut dikarena media media demonstrasi dan eksperimen berbasis video animasi dan power point memiliki keunggulan-keunggulan yaitu tidak banyak memerlukan peralatan, Pengembangan konsep terarah dan konsep yang akan dipelajari akan lebih mudah diingat karena siswa melihat fakta-fakta secara langsung. Pembelajaran melalui metode demonstrasi berdampak positif terhadap merangsang siswa untuk berpikir, memberikan kesempatan kepada siswa untuk secara aktif memikirkan lebih lanjut sesuai dengan apa yang dilihat dari proses demonstrasi itu . Dengan menggunakan media animasi video menambah penguasaan dan pemahaman kompetensi yang dibelajarkan karena media yang digunakan mengurangi abstraksi kompetensi sehingga peserta didik mampu mengkonstruksi pengetahuan dan keterampilan secara bermakna dan mampu diinternalisasi dalam memori jangka panjang (Dewi \& Handayani, 2021; Mayang Ayu Sunami \& Aslam, 2021). Pembelajaran yang menarik tentunya mendukung tingkat pemahaman siswa dalam proses pembelajaran (Alexander et al., 2018). Keterbaruan media yang dikembangkan diharapkan mampu meningkatkan kreativitas dan aktivitas siswa dalam memahami materi (Nugraheni, 2018). Bahwa upaya dilakukan dengan mengembangkan media demonstrasi dan eksperimen berbasis video animasi untuk materi kelarutan dan hasil kali kelarutan.

Temuan kedua menunjukkan media demonstrasi dan eksperimen lebih baik dalam meningkatkan keterampilan pemecahan masalah siswa daripada pembelajaran menggunakan power point. Hal ini terjadi karena dalam penelitian ini, pembelajaran di kelas eksperimen memberikan pengalaman belajar menggunakan penerapan teknologi dalam pembelajaran untuk mendukung revolusi industri 4.0 yang memiliki tantangan daripada pembelajaran secara konvesional. Melatih siswa untuk memecahkan masalah 
nyata dapat meningkatkan keterampilan pemecahan masalah (Yu et al., 2015; Zhong \& Xu, 2019). Dengan media tersebut mendorong peserta didik untuk menemukan sendiri konsep penjumlahan pecahan dengan penyebut berbeda sehingga pembelajaran menjadi lebih bermakna dan tahan lama bagi peserta didik (Andriyani \& Suniasih, 2021; S. Wahyuni et al., 2015). Pemecahan masalah tersebut dimaksudkan mampu memberikan solusi untuk mengatasi kesulitan belajar siswa (Gunantara et al., 2014; Syazali, 2015). Oleh karena itu, media demonstrasi dan eksperimen berbasis video animasi yang materi kelarutan dan hasil kelarutan dikemas secara nyata dalam kehidupan sehari- hari sehingga dapat meningkatkan keterampilan pemecahan masalah dalam proses pembelajaran.

Temuan ini diperkuat dengan temuan sebelumnya yang menyatakan media demostrasi dapat meningkatkan pemahaman konsep siswa (Nurhayati et al., 2014). Pembelajaran menggunakan media video animasi dapat meningkatkan aktivitas belajar siswa menjadi aktif (Agustiana \& Rusmana, 2018; Stoll et al., 2021; Wouters et al., 2019). Temuan lain juga menyatakan melalui media eksperimen siswa akan mendapatkan pembelajaran bermakna (Anggraeny et al., 2019; Setyowati \& Mawardi, 2018). Dari pembahasan, media demonstrasi dan eksperimen berbasis video animasi untuk materi kelarutan dan hasil kali kelarutan efektif digunakan pada proses pembelajaran. selain itu media ini juga dapat digunakan pada materi pembelajaran lainnya. Adanya media demonstrasi dan eksperimen berbasis video animasi untuk materi kelarutan dan hasil kali kelarutan diharapkan dapat membantu siswa memahami materi dan membantu guru dalam menyampaikan materi. Sehingga siswa dapat meningkatkan hasil belajarnya

\section{SIMPULAN DAN SARAN}

Terdapat perbedaaan signifikan antara kelas eksperimen dengan menggunakan media demonstrasi dan eksperimen berbasis video animasi dan kelas kontrol dengan media power point. Hal tersebut menunjukkan media demonstrasi dan eksperimen berbasis video animasi untuk materi kelarutan dan hasil kali kelarutan dapat digunakan pada proses pembelajaran dan meningkatkan hasil belajar siswa.

\section{DAFTAR RUJUKAN}

Adnan, F., Prasetyo, B., \& Nuriman, N. (2017). Usability testing analysis on the Bana game as education game design references on junior high school. Jurnal Pendidikan IPA Indonesia, 6(1), 88-94. https://doi.org/10.15294/jpii.v6i1.9597.

Agussani. (2020). The Use of Visual Basis Learning Strategy in Social Science: Facing the Industrial Revolution 4 . 0 Era. International Journal of Research and Innovation in Social Science (IJRISS), IV(3), 32-39.

Agustiana, L., \& Rusmana, I. M. (2018). Pemanfaatan Microsoft Power Point sebagai Alternatif Media. Prosiding Seminar Dan Diskusi Nasional Pendidikan Dasar, 374-379. http://journal.unj.ac.id/unj/index.php/psdpd/article/view/10164.

Alexander, A., Rahayu, H. M., \& Kurniawan, A. D. (2018). Pengembangan Penuntun Praktikum Fotosintesis Berbasis Audio Visual Menggunakan Program Camtacia Studio di SMAN 1 Hulu Gurung. Jurnal Pendidikan Sains Indonesia, 6(2), 75-82. https://doi.org/10.24815/jpsi.v6i2.12075.

Andriyani, N. L., \& Suniasih, N. W. (2021). Development Of Learning Videos Based On Problem-Solving Characteristics Of Animals And Their Habitats Contain in Science Subjects On 6th-Grade. Journal of Education, 5(1), 37-47. https://doi.org/10.23887/jet.v5i1.32314.

Anggraeny, T. K., Rohana, R., \& Jayanti, J. (2019). Pengaruh Pendekatan Metaphorical Thinking terhadap Kemampuan Berpikir Kritis dan Kecerdasan Emosional Siswa SMAN 4 Kayuagung. Jurnal Pendidikan Matematika RAFA, 5(1), 57-69. https://doi.org/10.19109/jpmrafa.v5i1.3001.

Anggreini, R. K., \& Dewi, N. R. (2020). Development of Ludo-Science Media with a Somatic Auditory Visual Intellectual (SAVI) Approach to Train the Activeness and Conceptual Understanding. Jurnal Penelitian Dan Pembelajaran IPA, 6(2), 241-267. https://doi.org/10.30870/jppi.v6i2.8677.

Anjarsari, E., Farisdianto, D. D., \& Asadullah, A. W. (2020). Pengembangan Media Audiovisual Powtoon pada Pembelajaran Matematika untuk Siswa Sekolah Dasar. Jurnal Matematika Dan Pendidikan Matematika, 5(2), 40-50. https://doi.org/10.26594/jmpm.v5i2.2084.

Anthony, E. (2019). (Blended) Learning: How Traditional Best Teaching Practices Impact Blended Elementary Classrooms. Journal of Online Learning Research, 5(1), 25-48. https: //doi.org/10.1007/978-3-7091-3443-6_1.

Asmawati, L. (2021). Peran Orang Tua dalam Pemanfaatan Teknologi Digital pada Anak Usia Dini. Jurnal Obsesi: Jurnal Pendidikan Anak Usia Dini, 6(1), 82-96. https://doi.org/10.31004/obsesi.v6i1.1170.

Atmojo, S. E., Muhtarom, T., \& Lukitoaji, B. D. (2020). The level of self-regulated learning and self-awareness in science learning in the covid-19 pandemic era. Jurnal Pendidikan IPA Indonesia, 9(4), 512-520. 
https://doi.org/10.15294/jpii.v9i4.25544.

Baharuddin, \& Dalle, J. (2018). Interactive courseware for supporting learners competency in practical skills Interactive Courseware for Supporting Learners Competency in Practical Skills. Turkish Online Journal of Educational Technology, 16(3).

Chang, T. Y., Hong, G., Paganelli, C., Phantumvanit, P., Chang, W. J., Shieh, Y. S., \& Hsu, M. L. (2021). Innovation of dental education during COVID-19 pandemic. Journal of Dental Sciences, 16(1), 15-20. https://doi.org/10.1016/j.jds.2020.07.011.

Cotet, G. B., Carutasu, N. L., \& Chiscop, F. (2020). Industry 4.0 Diagnosis from an iMillennial Educational Perspective. Edcation Science, 10(21). https://doi.org/10.3390/educsci10010021.

Darihastining, S., Aini, S. N., Maisaroh, S., \& Mayasari, D. (2020). Penggunaan Media Audio Visual Berbasis Kearifan Budaya Lokal pada Anak Usia Dini. Jurnal Obsesi : Jurnal Pendidikan Anak Usia Dini, 5(2), 1594-1602. https://doi.org/10.31004/obsesi.v5i2.923.

Dewi, F. F., \& Handayani, S. L. (2021). Pengembangan Media Pembelajaran Video Animasi En-Alter Sources Berbasis Aplikasi Powtoon Materi Sumber Energi Alternatif Sekolah Dasar. Jurnal Basicedu, 5(4), 2530-2540. https://doi.org/10.31004/basicedu.v5i4.1229.

Dwijayanti, I., Nugroho, A. A., \& Pratiwi, Y. I. (2020). Meta-Analysis: the Effect of Problem Approach and Inquiry Approach Toward Students' Mathematical Critical Thinking Skill Over the Past 4 Years. AlJabar : Jurnal Pendidikan Matematika, 11(1), 1-10. https://doi.org/10.24042/ajpm.v11i1.4944.

Fadhilaturrahm, Ananda, R., \& Yolanda, S. (2021). Persepsi Guru Sekolah Dasar terhadap Pembelajaran Jarak Jauh di Masa Pandemi Covid 19. Jurnal Basicedu, 5(3), 1683-1688. https://doi.org/10.31004/basicedu.v5i3.1187.

Fadhli, M. (2015). Pengembangan Media Pembelajaran Berbasis Video Kelas IV Sekolah Dasar. Jurnal Dimensi Pendidikan Dan Pembelajaran, 3(1), 24-29. http://dx.doi.org/10.24269/dpp.v3i1.157.

Fauzi, H. A., Komalasari, K., \& Malik, Y. (2017). Utilization of Audio Visual Media to Improve Student Learning Result in IPS Learning. International Journal Pedagogy of Social Studies, 2(1), 88-103. https://doi.org/10.17509/ijposs.v2i1.8666.

Gunantara, Suarjana, \& Riastini. (2014). Penerapan Model Pembelajaran Problem Based Learning Untuk Meningkatkan Kemampuan Pemecahan Masalah Matematika Siswa Kelas V. Jurnal Mimbar PGSD Universitas Pendidikan Ganesha, 2(1). https://doi.org/10.23887/jjpgsd.v2i1.2058.

Hidayah, N., Soeprodjo, \& Latifah. (2013). Keefektifan Model Pembelajaran Problem Based Instruction Terhadap Hasil Belajar. Chemistry in Education, 2(1).

Hua, T., Liang, C., Min, G., Li, K., \& Chunxi Xiao. (2020). Generating video animation from single still image in social media based on intelligent computing. Journal of Visual Communication and Image Representation, 71, 102812. https://doi.org/10.1016/j.jvcir.2020.102812.

Hussin, A. A. (2018). Education 4.0 Made Simple : Ideas For Teaching. International Journal of Education \& Literacy Studies, 6(3), 92-98.

Kartikawati, A., \& Azizah, U. (2017). Keterampilan Proses Sains Peserta Didik Melalui Penerapan Model Pembelajaran Learning Cycle 7-E pada Materi Laju Reaksi Kelas Xi di SMA Negeri 1 Krembung. Unesa Journal of Chemical Education, 6(2), 229-237.

Khairunnufus, U., Laksmiwati, D., Hadisaputra, S., \& Siahaan, J. (2019). Pengembangan Modul Praktikum Kimia Berbasis Problem Based Learning Untuk Kelas XI SMA. Chemistry Education Practice, 1(2), 36. https://doi.org/10.29303/cep.v1i2.981.

Liao, Y., Rocha, E., Deschamps, F., \& Brezinski, G. (2018). The Impact of the Fourth Industrial Revolution : a Cross-Country/Region Comparison. Production, 5411. https://doi.org/10.1590/01036513.20180061.

Martin, F., Budhrani, K., Kumar, S., \& Ritzhaupt, A. (2019). Award-winning faculty online teaching practices: Roles and competencies. Online Learning Journal, 23(1), 184-205. https://doi.org/10.24059/olj.v23i1.1329.

Mayang Ayu Sunami, \& Aslam. (2021). Pengaruh Penggunaan Media Pembelajaran Video Animasi Berbasis Zoom Meeting terhadap Minat dan Hasil Belajar IPA Siswa Sekolah Dasar. Jurnal Basicedu, 5(4), 19. https://doi.org/10.31004/basicedu.v5i4.1129.

Muhammad Fikri, Muhammad Zaki Ananda, N. F. (2021). Kendala Dalam Pembelajaran Jarak Jauh di Masa Pandemi Covid-19: Sebuah Kajian Kritis. Jurnal Education and Development Institut Pendidikan Tapanuli Selatan, 9(1), 145-148. https://doi.org/10.37081/ed.v9i1.2290.

Muslina, M., Halim, A., \& Khaldun, I. (2018). Kelayakan Media Animasi Hukum Newton Ii Tentang Gerak Pada Bidang Miring Dan Katrol Di Sma Kabupaten Aceh Besar. Jurnal IPA \& Pembelajaran IPA, 1(1), 64-72. https://doi.org/10.24815/jipi.v1i1.9568.

Naimah, J., Winarni, D. S., \& Widiyawati, Y. (2019). Pengembangan Game Edukasi Science Adventure Untuk Meningkatkan Keterampilanpemecahan Masalah Siswa. Jurnal Pendidikan Sains Indonesia 
(Indonesian Journal of Science Education), 7(2), 91-100. https://doi.org/10.24815/jpsi.v7i2.14462. Nessa, W., Hartono, Y., \& Hiltrimartin, C. (2017). Pengembangan Buku Siswa Materi Jarak pada Ruang Dimensi Tiga Berbasis Science, Technology, Engineering, and Mathematics (STEM) Problem-Based Learning di Kelas X. Jurnal Elemen, 3(1), 1. https://doi.org/10.29408/jel.v3i1.273.

Ntobuo, N. E., Arbie, A., \& Amali, L. N. (2018). The development of Gravity Comic Learning Media Based on Gorontalo Culture. Jurnal Pendidikan IPA Indonesia, 7(2), 246-251. https://doi.org/10.15294/jpii.v7i2.14344.

Nugraheni, D. (2018). Project Based Learning in Heat and Transfer Material to Increase Student's Creativity. Jurnal Penelitian Pembelajaran Fisika, 9(2), 73-79. https://doi.org/10.26877/jp2f.v9i2.2798.

Nurhayati, N., Fadilah, S., \& Mutmainah, M. (2014). Penerapan Metode Demonstrasi Berbantu Media Animasi Software Phet Terhadap Hasil Belajar Siswa Dalam Materi Listrik Dinamis Kelas X Madrasah Aliyah Negeri 1 Pontianak. Jurnal Penelitian Fisika Dan Aplikasinya (JPFA), 4(2), 1-7. https://doi.org/10.26740/jpfa.v4n2.p1-7.

Panjaitan, N. Q., Yetti, E., \& Nurani, Y. (2020). Pengaruh Media Pembelajaran Digital Animasi dan Kepercayaan Diri terhadap Hasil Belajar Pendidikan Agama Islam Anak. Jurnal Obsesi : Jurnal Pendidikan Anak Usia Dini, 4(2), 588. https://doi.org/10.31004/obsesi.v4i2.404.

Panjaitan, R. G. P., Titin, \& Putri, N. N. (2020). Multimedia Interaktif Berbasis Game Edukasi Sebagai Media Pembelajaran Materi Sistem Pernapasan Di Kelas XI SMA. Jurnal Pendidikan Sains Indonesia (Indonesian Journal of Science Education), 8(1), 141-151. https://doi.org/10.24815/jpsi.v8i1.16062.

Primasari, R., \& Herlanti, Y. (2015). Penggunaan Media Pembelajaran Di Madrasah Aliah Negeri Se-Jakarta Selatan. Edusains UIN Syarif Hidayatullah, 6(1), 67-72. https://doi.org/10.15408/es.v6i1.1101.

Purwaningsih, E., Sari, S. P., Sari, A. M., \& Suryadi, A. (2020). The Effect Of Stem-Pjbl And Discovery Learning On Improving Students ' Problem-Solving Skills Of The Impulse And Momentum Topic. Jurnal Pendidikan IPA Indonesia, 9(4), 465-476. https://doi.org/10.15294/jpii.v9i4.26432.

Quezada, R. L., Talbot, C., \& Quezada-Parker, K. B. (2020). From Bricks and Mortar to Remote Teaching: A Teacher Education Program's Response to COVID-19. Journal of Education for Teaching, 46(4), 472483. https://doi.org/10.1080/02607476.2020.1801330.

Rahim, A., Hamdi, S., \& Arcana, I. N. (2020). Developing Bilingual Learning Multimedia in Integral Application Learning Material For Vocational School. Al-Jabar: Jurnal Pendidikan Matematika, 11(2), 201-210. https://doi.org/10.24042/ajpm.v11i2.6816.

Rasmitadila, Aliyyah, R. R., Rachmadtullah, R., Samsudin, A., Syaodih, E., Nurtanto, M., \& Tambunan, A. R. S. (2020). The perceptions of primary school teachers of online learning during the covid-19 pandemic period: A case study in Indonesia. Journal of Ethnic and Cultural Studies, 7(2), 90-109. https://doi.org/10.29333/ejecs/388.

Santhalia, P. W., \& Sampebatu, E. C. (2020). Pengembangan multimedia interaktif dalam membantu pembelajaran fisika di era Covid-19. Jurnal Inovasi Pendidikan IPA, 6(2). https://doi.org/10.21831/jipi.v6i2.31985.

Setyowati, N., \& Mawardi, M. (2018). Sinergi Project Based Learning dan Pembelajaran Bermakna untuk Meningkatkan Hasil Belajar Matematika. Scholaria: Jurnal Pendidikan Dan Kebudayaan, 8(3), 253263. https://doi.org/10.24246/j.js.2018.v8.i3.p253-263.

Stoll, J. A., Ranahan, M., Richbart, M. T., Brennan-Taylor, M. K., Taylor, J. S., Brady, L., \& Singh, R. (2021). Development of Video Animations to Encourage Patient-driven Deprescribing: A Team Alice Study. Patient Education and Counseling. https://doi.org/10.1016/j.pec.2021.03.041.

Sudiana, I. K. S., Suja, I. W., \& Mulyani, I. (2019). Analisis Kesulitan Belajar Kimia Siswa Pada Materi Kelarutan Dan Hasil Kali Kelarutan. Jurnal Pendidikan Kimia Indonesia, 3(1), 7. https://doi.org/10.23887/jpk.v3i1.20943.

Syafari, Y., \& Montessori, M. (2020). Analisis Pembelajaran Daring Terhadap Motivasi Belajar Dan Prestasi Belajar Siswa Dimasa Pandemi Covid-19. Jurnal Basicedu, 5(3), 1295-1303. https://doi.org/10.31004/basicedu.v5i3.872.

Syazali, M. (2015). Pengaruh Model Pembelajaran Creative Problem Solving Berbantuan Media Maple 11 Terhadap Kemampuan Pemecahan Masalah Matematis. Al-Jabar : Jurnal Pendidikan Matematika, 6(1), 91-98. https://doi.org/10.24042/ajpm.v6i1.58.

Tomita, K. (2018). Does the Visual Appeal of Instructional Media Affect Learners' Motivation Toward Learning? TechTrends, 62(1), 103-112. https://doi.org/10.1007/s11528-017-0213-1.

Ulfah, T., Khaldun, I., \& Rusman. (2016). Analisa kesulitan Pemahaman Konsep Kelarutan dan Hasil Kali Kelarutan Pada Siswa SMA Inshafuddin Tahun Ajaran 2015 / 2016. Jurnal Ilmiah Mahasiswa Pendidikan Kimia (JIMPK), 1(4), 43-51.

W. Tabor, S., \& P. Minch, R. (2013). Student Adoption \& Development of Digital Learning Media: Action 
Research \& Recommended Practices. Journal of Information Technology Education: Research, 12(5), 203-223. https://doi.org/10.28945/1882.

Wahyuni, E. S., \& Yokhebed, Y. (2019). Deskripsi Media Pembelajaran Yang Digunakan Guru Biologi Sma Negeri Di Kota Pontianak. Jurnal Pendidikan Informatika Dan Sains, 8(1), 32. https://doi.org/10.31571/saintek.v8i1.1105.

Wahyuni, S., Isnarto, \& Wuryanto. (2015). Pengembangan Karakter Kedisiplinan Dan Kemampuan Pemecahan Masalah Melalui Model Laps-Heuristik Materi Lingkaran Kelas-Viii. Unnes Journal of Mathematics Education, 4(2). https://doi.org/10.15294/ujme.v4i2.7594.

Widikasih, P. A., Widiana, I. W., \& Margunayasa, G. (2021). Online Learning Problems for Elementary School Students. Journal of Education Research and Evaluation, 5(3), 489-497. https://doi.org/10.23887/jere.v5i3.34254.

Wijayanti, R. M., \& Fauziah, P. Y. (2020). Perspektif dan Peran Orangtua dalam Program PJJ Masa Pandemi Covid-19 di PAUD. Jurnal Obsesi: Jurnal Pendidikan Anak Usia Dini, 5(2), 1304-1312. https://doi.org/10.31004/obsesi.v5i2.768.

Wouters, T., Soomers, J., Smink, M., A.Smitc, R., Plaisier, M., Houtermand, S., L.Bekkersa, R., \& Angélique A.Schiffere Victor. (2019). The effect of an animation video on consultation time, anxiety and satisfaction in women with abnormal cervical cytology: Animation video reduces colposcopy time. Preventive Medicine Reports, 13, 238-243. https://doi.org/10.1016/j.pmedr.2019.01.005.

Yu, K. C., Fan, S. C., \& Lin, K. Y. (2015). Enhancing Students' Problem-Solving Skills Through Context-Based Learning. International Journal of Science and Mathematics Education, 13(6), 1377-1401. https://doi.org/10.1007/s10763-014-9567-4.

Zhong, L., \& Xu, X. (2019). Developing real life problem-solving skills through situational design: a pilot study. Educational Technology Research and Development, 67(6), 1529-1545. https://doi.org/10.1007/s11423-019-09691-2. 